\title{
EKSPLORASI DAN IDENTIFIKASI TRICHODERMA ENDOFITIK PADA PISANG
}

\author{
Johanna Taribuka ${ }^{1}$, Christanti Sumardiyono ${ }^{2}$, SM Widyastuti ${ }^{3}$, \& Arif Wibowo $^{2}$ \\ 1Jurusan Agroteknologi Fakultas Pertanian Universitas Pattimura \\ Jl. Martha Alfons, Kampus Poka-Ambon, 97233 \\ ${ }^{2}$ Departemen Hama dan Penyakit Tumbuhan Fakultas Pertanian Universitas Gadjah Mada \\ J1. Flora 1, Bulaksumur, Yogyakarta, 55281 \\ ${ }^{3}$ Laboratorium Perlindungan dan Kesehatan Hutan Fakultas Kehutanan \\ Universitas Gadjah Mada Jl. Agro No.1 Bulaksumur, Yogyakarta, 55281 \\ E-mail: anontari@yahoo.com
}

\begin{abstract}
Exploration and identification of endophytic Trichoderma in banana. Endophytic fungi Trichoderma is an organism that can used as biocontrol agent. This study aims to isolate and identify endophytic Trichoderma in roots of healthy banana plants from three districts in Yogyakarta, which will be used as biological control agent against the pathogen Fusarium oxysporum f.sp. cubense. Isolation was conducted using TSM (Trichoderma Selective Medium). We obtained six isolates of endophytic Trichoderma spp., i.e., Swn-1, Swn-2, Ksn, Psr-1, Psr-2, and Psr-3. Molecular identification was done by using ITS1 and ITS2 primer pain and sequenced. The sequence of DNA obtained was analysed and compared with NCBI database by using BLAST-N programe. The results showed that all isolates were amplified at 560-bp. Phylogenetic analysis showed that isolates Swn-1, Swn-2 and Psr-1 are homologous to Trichoderma harzianum, isolate Ksn homologous to Trichoderma asperrellum, isolate Psr-2 homologous to Trichoderma gamsii, and isolate Psr-3 homologous to Trichoderma koningiopsis, with the homologous value of $99 \%$.
\end{abstract}

Key words: Identification, banana, Fusarium oxysporum f.sp. cubense, Trichoderma endophytic

\begin{abstract}
ABSTRAK
Eksplorasi dan Identifikasi Trichoderma Endofitik Pada Pisang. Jamur Trichoderma endofitik merupakan salah satu organisme yang dapat digunakan sebagai agens pengendali hayati. Penelitian ini bertujuan untuk mengisolasi dan mengidentifikasi Trichoderma endofitik dari akar tanaman pisang sehat yang berasal dari tiga kabupaten di Provinsi DI Yogyakarta, yang akan digunakan sebagai agens pengendali hayati terhadap patogen Fusarium oxysporum f.sp. cubense pada pisang. Isolasi menggunakan medium TSM (Trichoderma Selective Medium). Dari hasil isolasi diperoleh enam isolat Trichoderma spp. yaitu isolat Swn-1, Swn-2, Ksn, Psr-1, Psr-2, dan Psr-3. Identifikasi secara molekuler menggunakan Primer ITS1 dan ITS2, dilanjutkan dengan sekuensing. Hasil sekuensing dianalisis dan dibandingkan dengan database NCBI menggunakan program BLAST-N. Hasil PCR memperlihatkan bahwa semua isolat teramplifikasi pada 560-bp. Analisis filogenetik menunjukkan bahwa isolat Swn-1, Swn-2 dan Psr-1 homolog dengan Trichoderma harzianum, isolat Ksn homolog dengan Trichoderma asperrellum, isolat Psr-2 homolog dengan Trichoderma gamsii, dan isolat Psr-3 homolog dengan Trichoderma koningiopsis, dengan nilai homologi masing-masing sebesar $99 \%$.
\end{abstract}

Kata kunci: Identifikasi, Fusarium oxysporum f.sp. cubense, pisang, Trichoderma endofitik

\section{PENDAHULUAN}

Jamur endofitik merupakan mikroorganisme yang hidup di dalam jaringan tanaman sehat tanpa menimbulkan gejala atau kerusakan pada inang (Tayung \& Jha, 2010; Aly et al., 2010). Jamur ini dapat diisolasi pada hampir semua bagian tanaman yang tumbuh di daerah tropis dengan iklim yang berbeda (Laran et al., 2002). Jamur endofitik lebih banyak diperoleh dari isolasi tanaman yang berada di lapangan dibanding tanaman yang ada di rumah kaca (Pimentel et al., 2006).

Salah satu jamur endofitik yang sering ditemukan dan mampu berperan sebagai agens pengendali hayati yaitu Trichoderma spp. Jamur ini dapat menekan patogen penyebab penyakit pada tanaman terutama patogen terbawa tanah melalui mekanisme mikoparasitisme, kompetisi dan antibiosis serta secara langsung dapat juga memacu pertumbuhan tanaman dan merangsang respons 
ketahanan terhadap penyakit (Widyastuti \& Hariani, 2006; Soesanto et al., 2011).

Trichoderma biasanya dianggap sebagai saprofit tanah, tetapi mampu berasosiasi dengan sistem perakaran tanaman, dan dikategorikan sebagai simbiosis (Harman et al., 2004). Populasi mikroba endofitik terbesar pada kebanyakan tanaman adalah spesies Trichoderma, yang di antaranya teridentifikasi sebagai spesies baru (Hanada et al., 2008; Samuels, 2006). Populasi Trichoderma endofitik tertinggi terdeteksi berada di dalam akar dan daun, dibandingkan di dalam batang dan buah, dan berpotensi sebagai antagonis (Sriwati et al., 2011).

Penelitian ini dilakukan untuk memperoleh dan mengidentifikasi Trichoderma endofitik yang berada pada akar pisang budidaya sehat yang akan digunakan sebagai agens pengendali hayati terhadap penyakit layu fusarium pada pisang (Fusarium oxysporum f.sp. cubense). Identifikasi merupakan faktor penting dalam monitoring mikroorganisme yang digunakan di lapangan. Secara konvensional identifikasi sangat bergantung pada morfologi dan karakterisasi isolat, tetapi tidak semua jamur mampu menghasilkan spora, sehingga sulit dilakukan identifikasi hanya dengan menggunakan morfologi.

Kemajuan metode modern seperti Genealogical Concordance Phylogenetic Species Recognition (GCPSR) dan sistem DNA-barcode merupakan metode yang dapat digunakan untuk identifikasi Trichoderma spp. di masa mendatang. Metode GCPSR digunakan untuk menganalisis hubungan gen, sedangkan sistem DNA-barcode didasarkan pada perbedaan nukleotida. Taylor et al. (2004) memanfaatkan konsep GCPSR untuk menganalisis lebih dari satu lokus gen, sehingga memberi kemudahan dalam taksonomi dan identifikasi Trichoderma. Druzhinina \& Kubicek (2005) dan Druzhinina et al. (2006) telah meninjau konsep spesies dan keragaman biologi pada jamur Trichoderma, yang secara morfologi jamur ini sulit untuk dibedakan, namun klasifikasi filogenetiknya telah mencapai 100 spesies, dan diperkirakan akan meningkat secara konsisten.

Analisis sekuens internal transcribed spacer region 1 dan 2 (ITS1 dan ITS2) pada DNA ribosomal dapat membantu untuk deskripsi dan karakterisasi spesies pada genus Trichoderma (Ospina-Giraldo et al., 1999; Jeewon et al., 2013). Seluruh analisis tersebut menggunakan amplifikasi PCR karena dapat menghasilkan produk yang akurat, sehingga dapat digunakan dalam melakukan diagnosis (McPherson \& Moller, 2006).

Penelitian ini bertujuan untuk mengisolasi dan mengidentifikasi Trichoderma endofitik dari akar tanaman pisang sehat di daerah DI Yogyakarta, yang akan digunakan sebagai agens pengendali hayati petogen Fusarium oxysporum f.sp cubense pada pisang.

\section{METODE PENELITIAN}

Tempat dan Waktu. Penelitian ini dilakukan di Sub Laboratorium Mikologi Departemen Hama dan Penyakit Tumbuhan dan Laboratorium Genetika dan Pemuliaan Tanaman Fakultas Pertanian Universitas Gadjah Mada. Penelitian dilaksanakan sejak bulan Desember 2012 hingga bulan Juli 2013.

Isolasi Trichoderma Endofitik. Sampel akar yang digunakan berasal dari beberapa jenis pisang budidaya sehat yang diambil dari daerah Kabupaten Sleman, Bantul dan Kulonprogo di DI Yogyakarta. Akar langsung diproses dalam 24 jam setelah dikoleksi. Akar dicuci dengan air mengalir untuk menghilangkan tanah yang menempel sebelum dilakukan sterilisasi permukaan (Regina et al., 2003). Akar dipotong dengan ukuran 0,5 $\mathrm{cm}$, didisinfeksi dengan $\mathrm{NaOCl} 0,5 \%$ selama 2 menit, dibilas dengan air steril sebanyak 3 kali dan dikeringanginkan. Akar dibelah membujur, kemudian diletakkan pada medium TSM (Trichoderma Selective Medium) dan diinkubasikan dalam keadaan gelap pada suhu $25^{\circ} \mathrm{C}$.

Amplifikasi PCR ITS dari DNA. Identifikasi Trichoderma endofitik dengan menggunakan teknik molekuler untuk mendeteksi dan membedakan antara Trichoderma endofitik menggunakan PCR dan dilanjutkan dengan sekuensing. Urutan basa dari primer ITS1 (forward) adalah 5'-TCC GTA GGT GAA CCT GCGG-3', dan ITS2 (reserve) adalah 5'-GCT GCG TTC TTC ATC GAT GC-3'. Untuk ekstraksi DNA, miselium jamur berumur lima hari pada medium PDA dipindahkan ke dalam erlenmeyer berisi $60 \mathrm{ml}$ medium PDB (Potato Dextrose Broth) dan ditumbuhkan selama enam hari pada suhu $25{ }^{\circ} \mathrm{C}$ di atas shaker dengan kecepatan $120 \mathrm{rpm}$.

Amplifikasi pada mesin PCR dengan campuran reaksi total volume $20 \mu 1$ yang terdiri dari Mega Mix Royal (MMR) $10 \mu 1$, akuabides $7 \mu 1$, pasangan primer ITS 1 dan ITS2 masing-masing $1 \mu 1$, serta template (sampel DNA) $1 \mu \mathrm{l}$, dengan konsentrasi 5 ug. Hasil campuran dimasukkan ke dalam tabung $2 \mu \mathrm{l}$ dan dimasukan ke dalam mesin PCR. Mesin PCR dijalankan dengan siklus denaturasi awal $95^{\circ} \mathrm{C}$ selama 5 menit satu siklus, dilanjutan dengan 35 siklus $\left(94^{\circ} \mathrm{C}\right.$ selama 1 menit untuk denaturasi, $55^{\circ} \mathrm{C}$ selama 1 menit untuk annealing, $72{ }^{\circ} \mathrm{C}$ selama 1 menit 30 detik untuk polimerasi DNA), kemudian ditambahkan satu siklus terakhir pada $72{ }^{\circ} \mathrm{C}$ 
selama 10 menit dan reaksi akan berakhir pada suhu 20 ${ }^{\circ} \mathrm{C}$. DNA hasil amplifikasi PCR digunakan untuk melakukan elektroforesis dengan gel agarosa 1,0\% dalam 1x larutan buffer TBE. Lima $\mu \mathrm{L}$ hasil amplifikasi PCR dicampur dengan $2 \mu \mathrm{L}$ loading dye dimasukan ke dalam sumuran gel dan dijalankan pada tegangan 100 volt selama 25 menit. Amplikon dari hasil PCR dikirim ke FirstBASE untuk dilakukan sekuensing. Urutan gen isolat yang telah disekuensing dengan primer ITS1 dan ITS2 disesuaikan dengan urutan gen Trichoderma yang tersedia di http://www.mycobank.org. untuk mengetahui kesamaan sekuensing dari spesies Trichoderma endofitik dengan menggunakan program dari BLAST-N data Genebank. Selanjutnya dilakukan alignment dengan metode ClustalW, dan hasil alignment digunakan sebagai data input untuk membuat pohon filogenetik dengan menggunakan metode Neighbour Joining, dan untuk penyusunan pohon filogenetik menggunakan perangkat lunak (software) Mega 5 (Tamura et al., 2011).

Karakterisasi Morfologi Trichoderma Endofitik. Identifikasi konvensional berdasarkan karakteristik secara makroskopis dan mikroskopis dengan menumbuhkan isolat-isolat yang ditemukan pada medium PDA (Potato Dextrose Agar). Identifikasi genera dan spesies dilakukan secara molekuler berdasarkan metode Narayan et al. (2007) dan secara morfologis menggunakan studi diskripsi berdasarkan Rifai (1969) dan Kubicek \& Harman (1998).

\section{HASIL DAN PEMBAHASAN}

Isolasi Trichoderma endofitik. Hasil isolasi Trichoderma endofitik pada akar beberapa jenis pisang budidaya sehat diperoleh enam isolat, yaitu empat isolat dari Kabupaten Sleman dan dua isolat dari Kabupaten Bantul (Tabel 1).
Tabel 1 menunjukkan tiga isolat (Swn-1, Ksn, dan Psr-2) diperoleh dari jenis pisang Ambon dengan lokasi yang berbeda, dan tiga isolat lainnya (Swn-2, Psr-1, dan Psr-3) diperoleh dari tiga jenis pisang, yaitu pisang pulut, pisang raja bandung dan pisang klutuk yang berasal dari dua lokasi yang berbeda juga.

Spesies Trichoderma dapat ditemukan dalam berbagai habitat dan merupakan komponen mikroflora tanah, dalam serasah tanaman serta mampu berasosiasi dengan jaringan tanaman (Nacimi et al., 2011). Hal ini membuktikan bahwa Trichoderma endofitik juga berasosiasi dengan jaringan akar pisang sehat seperti yang telah didapati sebelumnya oleh Soesanto et al. (2011) yaitu Trichoderma harzianum, sedangkan Trichoderma asperellum dan Trichoderma koningiopsis didapat oleh Xia et al. (2011). Trichoderma gamsii merupakan salah satu Trichoderma endofitik yang pertama ditemukan berasosiasi dalam akar pisang.

Beberapa Trichoderma endofitik lain yang telah diisolasi pada jaringan berbagai macam tanaman antara lain strain Trichoderma DIS70a, DIS 219b, DIS 219f dan DIS172ai pada jaringan Theobroma cacao yang digunakan sebagai agens pengendali hayati penyakit kakao (Holmes et al., 2004; Bailey et al., 2009), Trichoderma viridae serta jamur endofitik lainnya yang diisolasi dari kulit batang Taxus baccata (Tayung \& Jha, 2010), Trichoderma atroviride yang diisolasi dari Campthoteca acumunata yang dapat menghasilkan metabolit Campthocin untuk menghambat aktivitas kanker (Pu et al., 2013), Trichoderma brevicompactum pada Allium sativum yang menghasilkan trichodermin yang digunakan untuk mengendalikan patogen Rhozoctonia solani dan patogen lain (Shentu et al., 2014), Trichoderma spp. yang diisolasi dari akar Coffee arabica yang mampu mengendalikan tracheomycosis pada kopi (Mulaw et al., 2013).

Tabel 1. Hasil eksplorasi Trichoderma endofitik di DI Yogyakarta

\begin{tabular}{cccc}
\hline No. & Nama Isolat & Jenis Pisang & Daerah Asal \\
\hline 1. & Swn-1 & Ambon & Sewon, Bantul \\
2. & Swn-2 & Pulut & Sewon, Bantul \\
3. & Ksn & Ambon & Kalasan Sleman \\
4. & Psr-1 & Raja Bandung & Palangsari, Sleman \\
5. & Psr-2 & Ambon & Palangsari, Sleman \\
6. & Psr-3 & Klutuk & Palangsari, Sleman \\
\hline
\end{tabular}




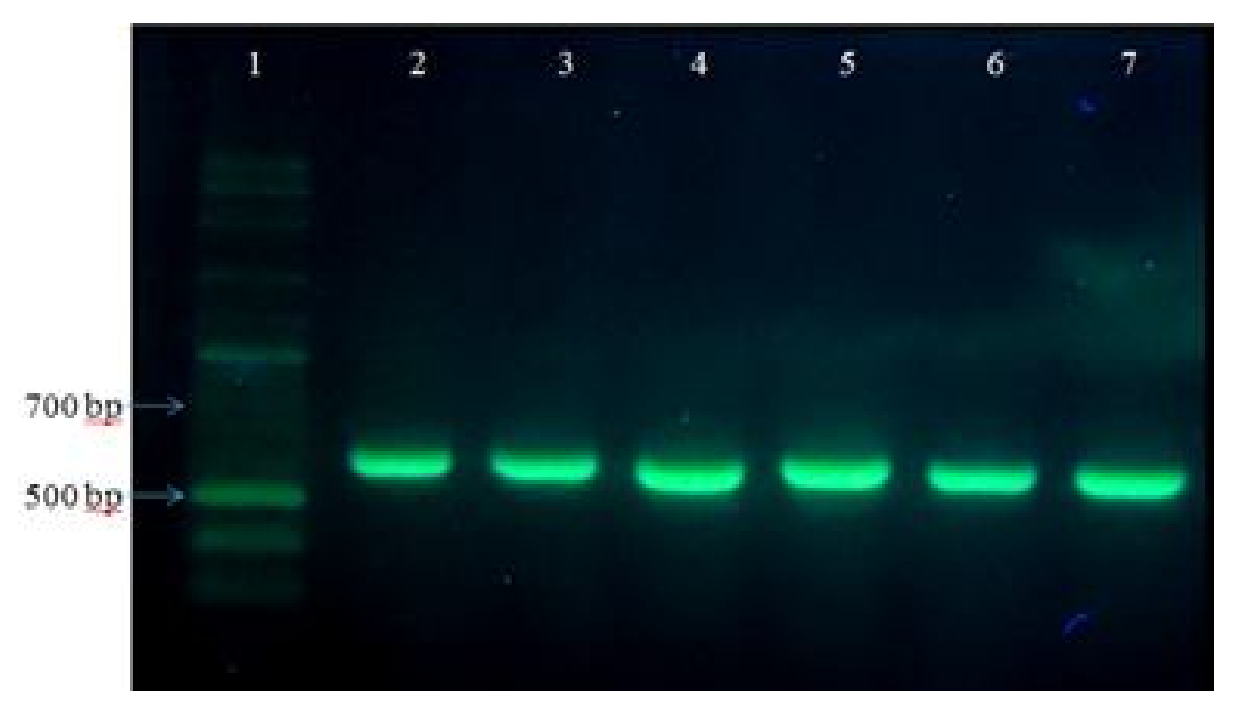

Gambar 1. Pola pita DNA isolat Trichoderma endofitik hasil elektroforesis; 1. marker MMR; 2. isolat Swn-1; 3. isolat Swn-2; 4. isolat Ksn; 5. isolat Psr-1; 6. isolat Psr-2; dan 7. isolat Psr-3

Amplifikasi PCR ITS dari DNA. Analisis PCR dengan menggunakan primer universal yaitu primer ITS1 dan ITS2 menunjukkan bahwa DNA enam isolat Trichoderma endofitik memiliki pita DNA dengan berat molekul sekitar 560 bp (Gambar 1). Hal ini sesuai dengan hasil penelitian Abd-Elsalam et al. (2003), bahwa penggunaan primer universal ITS1dan ITS2 dalam analisis PCR untuk analisis jamur, menghasilkan pita DNA berkisar antara $550-570 \mathrm{bp}$.

Hasil analisis sekuens ITS DNA berdasarkan database pada program BLAST-N menunjukkan, bahwa isolat Swn-1, isolat Swn-2 dan isolat Psr-1 mempunyai hubungan kekerabatan dengan Trichoderma harzianum, isolat Ksn dengan Trichoderma asperellum, isolat Psr-2 dengan Trichoderma gamsii dan isolat Psr3 dengan Trichoderma koningiopsis, dengan tingkat kemiripan $99 \%$ (Tabel 2).

Pohon filogenetik (Gambar 2) menunjukkan bahwa isolat mengelompok menjadi 3 klaster, yaitu isolat Psr-1, isolat Swn-2 dan isolat Swn-1 mengelompok menjadi satu klaster dan berkerabat dekat dengan Trichoderma harzianum dengan nilai bootstrap 100, isolat $\mathrm{Ksn}$, salah satu isolat yang diisolasi dari jenis pisang ambon mengelompok menjadi 1 klaster tersendiri, berkerabat dekat dengan Trichoderma asperellum dengan nilai booststrap 100, sedangkan isolat Psr-2 dan Psr-3 mengelompok menjadi satu klaster. Isolat Psr-2 berkerabat dekat dengan Trichoderma gamsii dengan nilai bootstrap 100, dan isolat Psr-3 berkerabat dekat dengan Trichoderma koningiopsis dengan nilai bootstrap 100, Hal ini menunjukkan bahwa sekuen DNA yang disusun berdasarkan gen 5,8S rRNA dapat memisahkan Trichoderma endofitik sampai pada spesies (Samuels et al., 2006).

Karakterisasi Morfologi Trihoderma Endofitik. Semua isolat ditumbuhkan dalam medium PDA dan diinkubasikan pada suhu $30^{\circ} \mathrm{C}$. Hasil pengamatan karakteristik morfologi enam isolat Trihoderma endofitik memperlihatkan adanya perbedaan warna koloni, bentuk koloni, bentuk konidiofor dan bentuk konidium dari masing-masing isolat (Gambar 3).

Hasil pengamatan koloni Trichoderma isolat Swn1, Swn-2, Ksn, dan Psr-1 membentuk lingkaran, berwarna hijau gelap pada setiap lingkaran. Koloni isolat Psr-2 dan Psr-3 tumbuh merata pada permukaan media dan konidium terbentuk pada pinggir cawan petri. Hal ini ditandai dengan pinggiran cawan petri yang berwarna hijau gelap (Gambar 3). Ciri-ciri yang sama dikemukakan oleh Soesanto et al. (2011) yang menemukan isolat Trichoderma 4 dengan bentuk koloni melingkar serta warna koloni hijau gelap pada lingkaran. Rata-rata koloni tumbuh penuh mencapai pinggiran cawan petri dalam waktu 5 hari. Karakteristik morfologi Trichoderma spp. tersebut selengkapnya pada Tabel 3.

Pada Tabel 3, ukuran konidium isolat Swn-1 (2,80 $\mathrm{x} 2,47 \mu \mathrm{m})$ lebih besar dari ukuran konidium isolat Swn$2(2,79 \times 2,42 \mu \mathrm{m})$, isolat $\mathrm{Ksn}(2,64 \times 1,87 \mu \mathrm{m})$, dan isolat Psr-1 (2,58 x 2,46 $\mu \mathrm{m})$, namun ukuran konidium isolat Psr-2 (2,83 x 2,52 $\mu \mathrm{m})$ lebih besar dari ukurana konidium isolat Psr-3 (2,87 x 1,93 $\mu \mathrm{m})$. Berdasarkan 
Tabel 2. Perbandingan tingkat kemiripan Isolat Trichoderma endofitik sampel akar pisang dan sekuen gen ITS1 dan ITS2 pada Gene Bank

\begin{tabular}{llcc}
\hline Isolat & \multicolumn{1}{c}{ Nama Spesies } & Homologi $(\%)$ & Gene Bank Accesion Number \\
\hline Swn-1 & Trichoderma harzianum & 99 & JN039051 \\
Swn-2 & Trichoderma harzianum & 99 & JN039051 \\
Ksn & Trichoderma asperellum & 99 & HQ671189 \\
Psr-1 & Trichoderma harzianum & 99 & JN039051 \\
Psr-2 & Trichoderma gamsii & 99 & JQ398842 \\
Psr-3 & Trichoderma koningiopsis & 99 & KF751670 \\
\hline
\end{tabular}

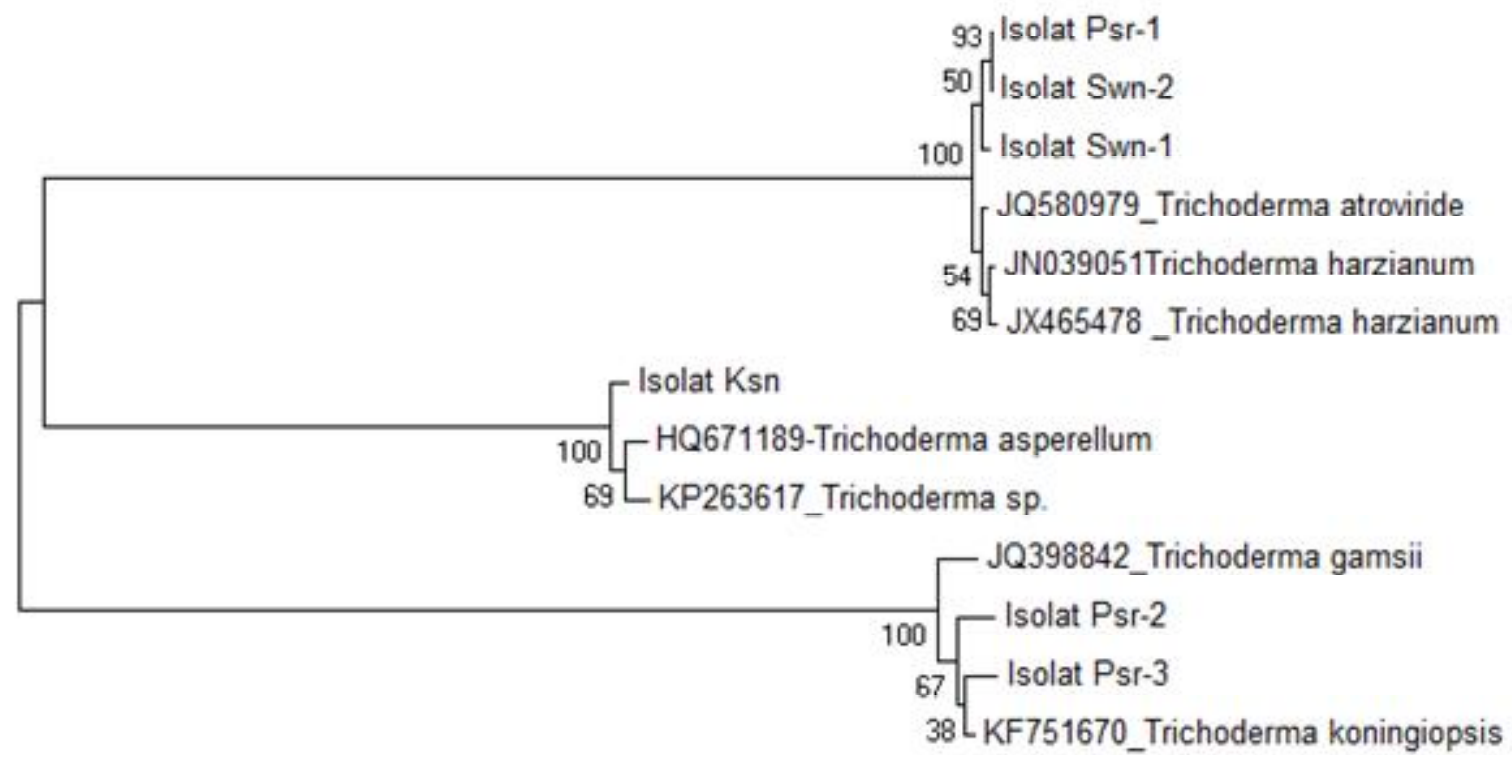

0.1

Gambar 2. Pohon filogenetik isolat Trichoderma endofitik berdasarkan NCBI

ukuran konidium dan fialid pada isolat Swn-1, isolat Swn2 dan isolat Psr-1 merupakan kisaran ukuran dari Trichoderma harzianum Rifai, yaitu ukuran konidium antara (2,5)2,7-3,5 x 2,1-2,6(-3,0) $\mu \mathrm{m}$ dan ukuran fialid $3,5-7,5 \times 2,5-3,8 \mu \mathrm{m}$. Warna konidium untuk keenam isolat Trichoderma adalah mempunyai warna konidium yang sama yaitu hijau. Bentuk konidium isolat Swn-1, Swn-2, Ksn, Psr-1 dan Psr-2 adalah sama yaitu oval dan bentuk konidium isolat Psr-3 adalah bulat. Dinding konidium isolat Swn-1, Swn-2, Psr-2 dan Psr-3 tidak berbeda yaitu tipis dan dinding konidium isolat Ksn dan Psr-1 adalah tebal (Kubicek \& Harman, 1998).

Ukuran fialid isolat Swn-1 (7,0 x 3,23 $\mu \mathrm{m})$ dan isolat Swn-2 $(6,99 \times 3,25 \mu \mathrm{m})$ tidak terpaut jauh, juga ukuran fialid isolat Ksn $(5,84 \times 2,95 \mu \mathrm{m})$ dan isolat Psr$1(5,43 \times 3,02 \mu \mathrm{m})$, sedangkan ukuran fialid Psr-2 (7,44 x 2,13 $\mu \mathrm{m})$ sangat berbeda dengan isolat Psr-3 $(8,3 \mathrm{x}$ 2,76 $\mu \mathrm{m})$. Sementara hifa isolat Swn-1, Swn-2, Ksn, Psr1, Psr-2 dan Psr-3 tidak ada perbedaan yaitu hialin dan bersekat (Rifai, 1969). 


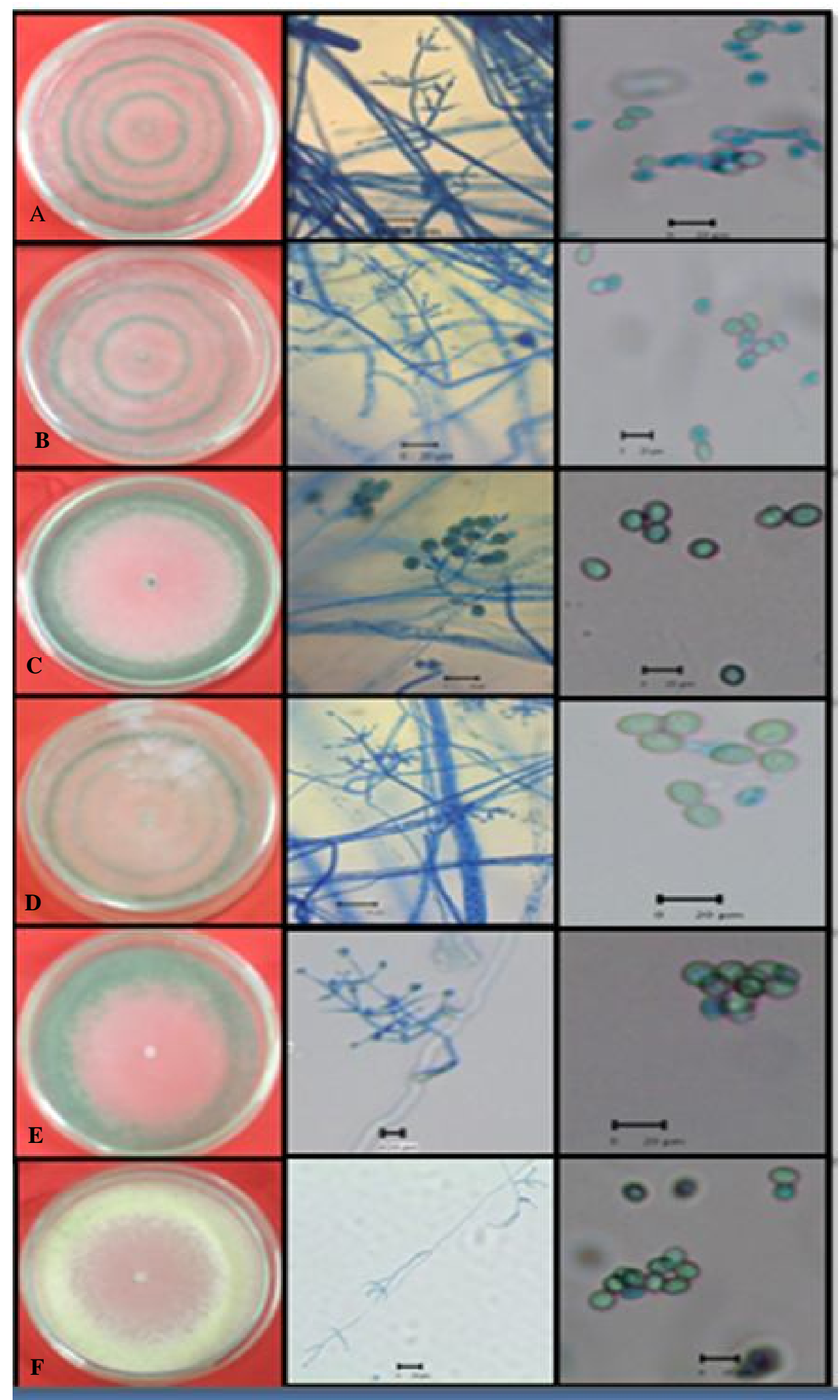

Gambar 3. Karakteristik morfologi isolat Trichoderma endofitik berumur 5 hari. A. Isolat Swn-1; B. Isolat Swn2; C. Isolat Ksn; D. Isolat Psr-1; E. Isolat Psr-2; dan F. Isolat Psr-3; Bar $=20 \mu \mathrm{m}$ 
Tabel 3. Karakteristik morfologi enam isolat Trichoderma endofitik

\begin{tabular}{lllllll}
\hline Morfologi & \multicolumn{5}{c}{ Isolat } \\
\cline { 2 - 5 } $\begin{array}{l}\text { Bentuk } \\
\text { koloni }\end{array}$ & $\begin{array}{l}\text { Sulat, } \\
\text { membentuk } \\
\text { lingkaran }\end{array}$ & $\begin{array}{l}\text { Swlat, } \\
\text { membentuk } \\
\text { lingkaran }\end{array}$ & $\begin{array}{l}\text { Bulat, } \\
\text { membentuk } \\
\text { lingkaran }\end{array}$ & $\begin{array}{l}\text { Bulat, } \\
\text { membentuk } \\
\text { lingkaran }\end{array}$ & $\begin{array}{l}\text { Tumbuh } \\
\text { merata pada } \\
\text { permukaan } \\
\text { media }\end{array}$ & $\begin{array}{l}\text { Tumbuh } \\
\text { merata pada } \\
\text { permukaan } \\
\text { media }\end{array}$ \\
\hline $\begin{array}{l}\text { Warna } \\
\text { koloni }\end{array}$ & Hijau gelap & Hijau gelap & Hijau gelap & Hijau gelap & Hijau gelap & $\begin{array}{l}\text { Hijau-kuning } \\
\text { kusam }\end{array}$ \\
\hline $\begin{array}{l}\text { Bentuk } \\
\text { konidium }\end{array}$ & Oval & Oval & Oval & Oval & Bulat & Oval \\
\hline $\begin{array}{l}\text { Ukuran } \\
\text { konidia }\end{array}$ & $2,80 \times 2,47 \mu \mathrm{m}$ & $2,79 \times 2,42 \mu \mathrm{m}$ & $2,64 \times 1,87 \mu \mathrm{m}$ & $2,58 \times 2,46 \mu \mathrm{m}$ & $2,83 \times 2,52 \mu \mathrm{m}$ & $3,21 \times 1,93 \mu \mathrm{m}$ \\
\hline $\begin{array}{l}\text { Warna } \\
\text { konidium }\end{array}$ & Hijau muda & Hijau muda & Hijau & Hijau muda & Hijau & Hijau \\
\hline $\begin{array}{l}\text { Dinding } \\
\text { konidium }\end{array}$ & Tipis & Tipis & Tebal & Tebal & Tipis & Tipis \\
\hline $\begin{array}{l}\text { Ukuran } \\
\text { fialid }\end{array}$ & $7,01 \times 3,23 \mu \mathrm{m}$ & $6,99 \times 3,25 \mu \mathrm{m}$ & $5,84 \times 2,95 \mu \mathrm{m}$ & $5,43 \times 3,02 \mu \mathrm{m}$ & $7,44 \times 2,13 \mu \mathrm{m}$ & $8,3 \times 2,76 \mu \mathrm{m}$ \\
\hline $\begin{array}{l}\text { Hifa } \\
\text { Hialin, }\end{array}$ & Hialin, & Hersekat & bersekat & $\begin{array}{l}\text { Hialin, } \\
\text { bersekat }\end{array}$ & $\begin{array}{l}\text { Hialin, } \\
\text { bersekat }\end{array}$ & $\begin{array}{l}\text { Hialin, } \\
\text { bersekat }\end{array}$ \\
\hline
\end{tabular}

\section{SIMPULAN}

Empat spesies Trichoderma yaitu, T. harzianum, T. asperellum, T. koningiopsis dan T. gamsii ditemukan sebagai Trihoderma endofitik yang berada di dalam akar beberapa jenis pisang budidaya sehat di DI Yogyakarta.

\section{SANWACANA}

Terima kasih kepada NUFFIC (AGRI 4 project UNPATTI) sebagai penyandang dana beasiswa dan Direktorat Pendidikan Tinggi, Kementrian Riset, Teknologi dan Pendidikan Tinggi sebagai penyandang dana penelitian melalui skim Hibah Doktor tahun 2015.

\section{DAFTAR PUSTAKA}

Abd-Elsalam KA, Aly IN, Abdel-Satar MA, Khalil MS, \& Verreet JA. 2003. PCR identification of fusarium genus based nuclear ribosomal-DNA sequence data. Afr. J. Biotechnol. 2(4): 82-85.

Aly AH, Debbab A, Kjer J, \& Proksch P. 2010. Fungal endophytes from higher plants: a prolific source of phytochemicals and other bioactive natural products. Fungal Diversity 41(1): 1-16.
Bailey BA, Strem MD, \& Wood D. 2009. Trichoderma species from endophytic associations within Theobroma cacao trichomes. Mycol. Res. 113(12): 1365-1376

Druzhinina IS, \& Kubicek CP. 2005. Species concepts and biodiversity in Trichoderma and Hypocrea: from aggregate species to species clusters. $J$. Zhejiang Univ. Sci. 6(2): 100-112.

Druzhinina IS, Kopchinskiy AG, \& Kubicek CP. 2006. The first 100 Trichoderma species charactherized by molecular data. Mycoscience 47: 55-64.

Hanada RE, de Jorge Souza T, Pomella AW, Hebbar KP, Pereira JO, Ismaiel A, \& Samuel GJ. 2008. Trichoderma martiale sp. nov., a new endophyte from sapwood of Teobroma cacao with a potential for biological control. Mycol. Res. 112(11): 1335-1343.

Harman GE, Howell CR, Veterbo A, Chet I, \& Lorito M. 2004. Trichoderma species-opportunistic, avirulent plant symbionts. Nat. Rev. Microbiol 2: 43-56. 
Holmes KA, Schroers HJ, Thomas SE, Evans HC, \& Samuels GJ. 2004. Taxonomy and biocontrol potential of a new species of Trichoderma from the Amazon basin of South America. Mycol. Prog. 3(3): 199-210.

Jeewon R, Itto J, Mahadeb D, Jaufeerallu-Fakim Y, Wang HK, \& Liu AR. 2013. DNA based identification and Phylogenetic characterisation of endophytix and saprobic fungi from Antidesma madagascariense, a medicinal plant in Mauritius. J. Mycol. 2013: 1-10.

Kubicek CP, \& Harman GE. 1998. Trichoderma and Gliocladium Vol.1. Basic biology, taxonomy and Genetic. Taylor \& Francis Ltd. 1 Gunpowder Square, London. UK. Taylor \& Francis Inc, 1900 Frost Road, Suite 101. Bristol. USA.

Laran S, Perello A, Simon MR, \& Mareno V. 2002. Isolation and analysis of endophytic mecroorganisms in wheat (Triticum aestivum L.) leaves. Word J. Microb. Biot. 18(7): 683-686.

McPherson MJ, \& Moller SG. 2006. PCR. Sec. Ed. Taylor \& Francis Group.270 Madison Avenue, New York. US.; 4 Park Square, Milton Park Abingdon. UK.

Mulaw TB, Druzhinina IS, Kubicek CP, \& Atanasova L. 2013. Novel endophytic Trichoderma spp. Isolated from healthy Coffea arabica roots are capable of controlling Coffee Tracheomycosis. Diversity 5: 750-766.

Naeimi S, Khodaparats S, Javan-Nikkhah M, Vagvolgyi C, \& Kredics L. 2011. Spesies patterns and phylogenetic relationships of Trichoderma strain in rice fields of Southern Caspian Sea, Iran. Cereal Res. Commun. 39(4): 560-568.

Paul N, Kim WK, Woo SK, Park MS, \& Yu SH. 2007. Fungal endophytes in roots of Aralia species and their antifungal activity. Plant Pathol. 23(4): 287294.

Ospina-Giraldo MD, Royse DJ, Chen X, Romaine CP, 1999. Molecular phylogenic analyses of biological control of Trichoderma harzianum and other biotypis of Trichoderma Associated with mushroom green mold. Phytopathology 89(4): 308-313.
Pimentel IC, Glienke-Blanco C, Gabardo J, Stuart RM \& Azevedo JL. 2006. Identification and colonization of endophytic fungi from soybean (Glycine max (L.) Merril) under different environmental conditions. Braz. Arch. Biol. Technol. 49(6): 705-711.

Pu X, Qu X, Chen F, \& Bao J, Zang G, \& Lou Y. 2013. Camptothecin-producing endophytic fungus Trichoderma atroviride LY357: isolation, identification, and fermentation conditions optimization for camptothecin production. Appl Microbiol. Biotechnol. 97(21): 9365-9375.

Geris dos Santos R, Rodrigues-Fo E, Rocha WC, \& Teixeira MFS. 2003. Endophytic fungi from Melia azedarach. World J. of Microbiol. Biot. 19(8): 767-770.

Rifai MA. 1969. A revision of the genus Trichoderma. Mycol. Papers 116(1):1-56.

Samuels GJ. 1996. Trichoderma: A review of biology and systematic of the genus. Mycol. Res. 100(8): 923-935.

Shentu X, Zhan X, Ma Z, Yu X, \& Zhang C. 2014. Antifungal activity of metabolites of endophytic fungus Trichoderma brevicompactum from garlic. Braz. J. Microbiol. 45(1): 248-254.

Soesanto L, Utami DS, \& Rahayuniati RF. 2011. Morphological characteristics of four Trichoderma isolates and two endophytic Fusarium isolates. Can. J. on Scientific and Industrial Res. 2(8): 294-306.

Sriwati R, Chamsudan TJ, \& Sukarman. 2011. Deteksi dan identifikasi cendawan endofotik Trichoderma yang berasosiasi pada tanaman Kakao. Agrista 15(1): 15-20.

Tamura K, Peterson D, Peterson N, Stecher G, Nei M, \& Kumar S. 2011. MEGA5: molecular evolutionary genetics analysis using maximum likelihood, evolutionary distance, and maximum parsimony methods. Mol. Biol. Evol. 28(10): 2731-2739.

Taylor JW, Spatafora J, O’Donnell K, Lutzoni F, James T, Hibbett DS, Geiser D, Bruns TD, Blackwell M. 2004. The Fungi. In: Cracraft J \& Donoghue MJ (Eds.) Assembling the Tree of Life. Oxford University Press, New York. Pp: 171-194. 
Tayung K \& Jha DK. 2010. Antimicrobial endophytic fungal assemblages inhabiting bark of Taxus baccata L. of Indo-Burma mega biodiversity hotspot. India J. Microbiol. 50 (Suppl 1): 74-81.

Widyastuti SM \& Hariani M. 2006. Peranan Trichoderma reesei E.G. Simmons pada pengendalian Damping off semai Cendana (Santalum album Linn.) J. Perlind. Tan. Indon. 12 (2): $62-73$.
Xia X, Lie TK, Qian X, Zheng Z, Huang Y, \& Shen Y. 2011. Species diversity, distribution, and genetic structure of endophytic and epiphytic Trichoderma associated with banana roots. Microb. Ecol. 61: 619-625. 